УДК: 631.62.633.14

\title{
ЕФЕКТИВНІСТЬ ВИРОЩУВАННЯ
}

(C) 2021 \section{ЖИТА ОЗИМОГО НА ОСУШУВАНИХ ҐРУНТАХ ПОЛІССЯ В УМОВАХ ЗМІН KЛIMATY}

\author{
С.M. Рижук, А.О. Мельничук², O.I. Савчук ${ }^{3}$, \\ Г.М. Кочик ${ }^{4}$, Т.Ю. Приймачук ${ }^{5}$
}

${ }^{1}$ доктор сільськогосподарських наук, професор, академік НААН

${ }^{2-4}$ кандидати сільськогосподарських наук

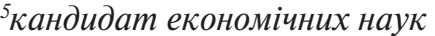

Інститут сільського господарства Полісся НААН, Київське шосе, 131, м. Житомир, 10007, Україна

e-mail: ${ }^{2}$ andriy_melnychuk@ukr.net, ${ }^{3,4}{ }^{4}$ runt17isgp@gmail.com, ${ }^{5}$ isgp.ek@gmail.com ORCID: ${ }^{20000-0002-7879-3691, ~{ }^{3} 0000-0002-6702-239 X,{ }^{5} 0000-0002-6088-1730}$

Надійшла 31.05.2021

Мета. Дослідити формування продуктивності та якості зерна жита озимого за різних рівнів органо-мінерального живлення. Методи. Польовий - проведення стаціонарного досліду, лабораторний - для визначення якісних показників ґрунту та зерна за загальноприйнятими методиками, обробка експериментальних даних - за допомогою комп'ютерної програми Microsoft Office Excel. Результати. Спостереження 2016-2020 рр. за динамікою вологозапасів у дерново-підзолистому осушеному ґрунті показали, що в період формування та наливу зерна запаси продуктивної вологи в шарі 0-100 см знижувалися до критичного рівня - 60-80 мм. В умовах низького вологозабезпечення ґрунту за біологічної системи удобрення (побічна продукція ріпаку озимого) отримано 2,69 т/га зерна (11,6\% приросту до абсолютного контролю). На фоні побічної продукції внесення рекомендованої для зони норми мінеральних добрив $\boldsymbol{N}_{60} \boldsymbol{P}_{60} K_{60}$ вихід зерна збільшився до 3,61 т/га. Найвищу продуктивність зерна відзначено за використання збільшеної (інтенсивної) норми мінеральних добрив $\boldsymbol{N}_{90} \boldsymbol{P}_{90} K_{90}$ р роздільним унесенням азоту в 3 етапи на фоні побічної продукції - 3,94 т/га. Виповненість зерна жита істотно не залежала від системи удобрення. Маса 1000 насінин становила 37,9-40,2 г, показник натури зерна був у межах 641 - 663 г/л. Уміст білка з унесенням добрив у варіантах становив 11,8-12,2 \%, на підвищеному фоні - 13,0, що на 1,2 \% більше, ніж за біологічної системи удобрення. Висновки. Найвищий рівень рентабельності вирощування жита озимого був за біологічної системи удобрення з використанням побічної продукції ріпаку озимого 152 \%. Хоча за використання підвищеної системи удобрення $\boldsymbol{N}_{90} \boldsymbol{P}_{90} K_{90}$ в поєднанні з побічною продукцією отримано найвищу врожайність зерна та вміст у ньому білка, рентабельність вирощування жита озимого знизилася до 70 \%. Тобто затрати на застосування мінеральних добрив підвищують собівартість і знижують рентабельність виробництва зерна.

Ключові слова: вологозабезпечення, сівозміна, система удобрення, продуктивність, якість, економічна ефективність.

DOI: https://doi.org/10.31073/agrovisnyk202108-09 
АГРОЕКОЛОГІЯ, РАДІОЛОГІЯ, МЕЛІОРАЦІЯ

Ефективність вирощування

жита озимого на осушуваних ґрунтах

Полісся в умовах змін клімату

Жито озиме - традиційна, найбільш цінна поліська культура, зерно якої використовують для виробництва хлібопекарського борошна. Як хлібна культура жито займає друге місце після пшениці, хоча за поживними якостями житній хліб переважає пшеничний і характеризується високою калорійністю та біологічною цінністю білка. Крім випічки хліба, зерно використовують для годівлі худоби в зерносумішах та як зелену рослину на ранній зелений корм і для випасання худоби. Житнє зерно, висівки, борошно - цінний концентрований корм. Солому використовують як корм у тваринництві, біоенергетичну сировину, а також для виготовлення паперу та предметів народного вжитку [1, 2].

Жито є добрим попередником для всіх сільськогосподарських культур. Це культура з високою алелопатичною активністю, $\epsilon$ гарним фрітосанітаром, має фрітоценотичну здатність до пригнічення бур'янів, особливо багаторічних. Воно $є$ перспективною продовольчою культурою, тому актуальним $\epsilon$ виробництво зерна за органічного способу вирощування [3-5].

Жито - стратегічна продовольча культура, для якої кліматичні умови Полісся найбільшою мірою відповідають її агробіологічним особливостям вирощування $[6,7]$. Проте вітчизняний титул «житниці Європи» стрімко втрачає свою популярність. Площі посівів продовжують скорочуватися, знижуються обсяги його виробництва. У сільськогосподарських підприємствах Житомирської області площі посіву пшениці озимої становлять понад 100 тис. га, жита - усього 10,7 тис. га із середньою врожайністю зерна 2,49 т/га.

Негативна динаміка пояснюється передусім низьким рівнем рентабельності. Більшість виробників культури не спеціалізуються на ній, відводячи площі під посів за залишковим принципом після пшениці та кукурудзи. На зовнішньому ринку основна проблема експорту жита - нестабільність.

Останнім часом проводили мало наукових досліджень з удосконалення технологій вирощування жита в зоні Полісся, а досліджень на осушуваних ґрунтах в умовах змін клімату взагалі немає. Тому пошук напрямів підвищення ефрективності виробництва зерна жита озимого способом оптимізації елементів технології вирощування $є$ необхідним і актуальним.

Мета досліджень - вивчити формування продуктивності та якості зерна жита озимого за різних рівнів живлення та визначити найбільш економічно обґрунтовану систему удобрення на осушеному дерново-підзолистому ґрунті.

Матеріали та методи досліджень. Дослідження проводили в стаціонарному досліді Інституту сільського господарства Полісся НААН. Ґрунт - дерново-підзолистий глеюватий супіщаний, осушений гончарним дренажем з одностороннім водно-повітряним режимом. Орний шар $(0-20 \mathrm{~cm})$ характеризується такими показниками: уміст гумусу - 1,27\%, загального азоту - 0,064\%, рухомого фросфрору - 84 мг/кг ґрунту, обмінного калію - 101 мг/кг ґрунту, $\mathrm{pH}_{\text {сол }}-5,2$, гідролітична кислотність - 2,25 мг · екв. I 100 ґрунту.

Жито вирощували в короткоротаційній зерновій сівозміні з таким чергуванням культур: люпин - ріпак озимий - жито озиме - кукурудза. Сорт - Фінал. Площа посівної ділянки - $48 \mathrm{~m}^{2}$, облікової $-28 \mathrm{~m}^{2}$, повторність - 3-разова. Основний спосіб обробітку ґрунту - оранка.

Схема досліду містила 6 варіантів: 1 без добрив (контроль); 2) - солома (побічна продукція ріпаку озимого); 3 - рекомендована для зони норма мінеральних добрив $\left(\mathrm{N}_{60} \mathrm{P}_{60} \mathrm{~K}_{60}\right) ; 4-$ солома $+\mathrm{N}_{30} \mathrm{P}_{30} \mathrm{~K}_{30} ; 5-$ солома $+\mathrm{N}_{60} \mathrm{P}_{60} \mathrm{~K}_{60} ; 6$ - солома $+\mathrm{N}_{90} \mathrm{P}_{90} \mathrm{~K}_{90}$. Азот уносили в 2 етапи: в основне (під час сівби) і у весняне підживлення; за підвищеної норми $\mathrm{N}_{90} \mathrm{P}_{90} \mathrm{~K}_{90}$ в 3 етапи $-\mathrm{N}_{30}$ під час сівби, $\mathrm{N}_{30}$ - виходу в трубку, $\mathrm{N}_{30}$ - наливу зерна. Заорювали солому в кількості 2,3-2,5 т/га.

У ґрунтових зразках визначали гумус за Тюріним (ДСТУ 4289:2004), рН ґрунту — методом прямої потенціометрії з використанням іон-селективних електродів за методикою ЦИНАО (ГОСТ 26483-85), легкогідролізований азот - методом Корнфільда, фоссфор і калій - за Кірсановим (ДСТУ 4405-2005); гідролітичну кислотність (ГОСТ 26212-91), вологу - термостатно-ваговим методом. Структурний аналіз рослин жита проводили за Майсуряном, уміст білка 
АГРОЕКОЛОГІЯ,

РАДІОЛОГІЯ, МЕЛІОРАЦІЯ

Ефективність вирощування

жита озимого на осушуваних грунтах

Полісся в умовах змін клімату

в зерні визначали за Лоурі. Узагальнення матеріалів та аналіз результатів досліджень здійснювали за Б.А. Доспєховим (1985) і програмою «STATISTICA».

Результати досліджень. Однією з важливих умов, які забезпечують отримання стабільних урожаїв на осушуваних землях із незадовільною роботою меліоративних мереж, $\epsilon$ оптимальне забезпечення їх ґрунтовою вологою впродовж періоду вегетації [8, 9].

Спостереження впродовж 2016-2020 рр. за динамікою вологозапасів у ґрунті свідчать про зростання дефіциту вологи вже до початку літа. Якщо на початок весняно-польових робіт запаси продуктивної вологи в метровому шарі ґрунту становили 120-200 мм, то в літній період вони знижувалися до 60-80 мм, тобто до критичного рівня (рис. 1).

За даними А.М. Алпатьєва $(1954,1966)$, якщо на дерново-підзолистих ґрунтах у метровому шарі запаси продуктивної вологи становлять менше 60 мм, то такий стан $€$ критичним. Зменшення кількості опадів на фоні високої температури повітря призводило до зниження рівня ґрунтових вод до 2-3 м (глибина закладання дрен $1,1 \mathrm{M})$.

Ґрунтово-повітряна посуха особливо негативно впливає на ріст і розвиток ярих культур. Озимі зернові культури менше реагують на літню посуху, завдяки достатнім весняним вологозапасам вони встигають сорормувати високу врожайність зерна. Винятком був 2020 р., коли за безсніжної зими і сухої весни рослини вийшли з перезимівлі в слабкому стані. Дощі в другій половині квітня дещо поліпшили стан посівів жита озимого. Найбільш сухим був 2016 р., коли під час наливу зерна за дефіциту опадів кількість вологи в ґрунті наблизилася до критичного значення, що негативно позначилося на формуванні врожайності зерна (табл. 1). Найсприятливішими за вологозабезпеченням були 2017 і 2018 рр. За рахунок рівномірного розподілу опадів упродовж вегетаційного періоду врожайність зерна сформувалася на органо-мінеральних фонах на рівні 4,12-4,85 т/га.

У середньому за 5 років досліджень у контрольному варіанті отримали 2,41 т/га зерна. Побічна продукція ріпаку озимого, яку використовували як органічне добриво, сприяла отриманню 11,6\% приросту врожаю жита.

За внесення рекомендованої норми мінеральних добрив $\mathrm{N}_{60} \mathrm{P}_{60} \mathrm{~K}_{60}$ урожайність зерна становила 3,50 т/га (приріст 45,2\% до абсолютного контролю).

Внесення $\mathrm{N}_{60} \mathrm{P}_{60} \mathrm{~K}_{60}$ на фоні соломи неістотно вплинуло на збільшення врожайності жита, а поєднання побічної продукції зі зменшеною вдвоє нормою $\mathrm{N}_{30} \mathrm{P}_{30} \mathrm{~K}_{30}$ знизило вихід зерна до 3,25 т/га.

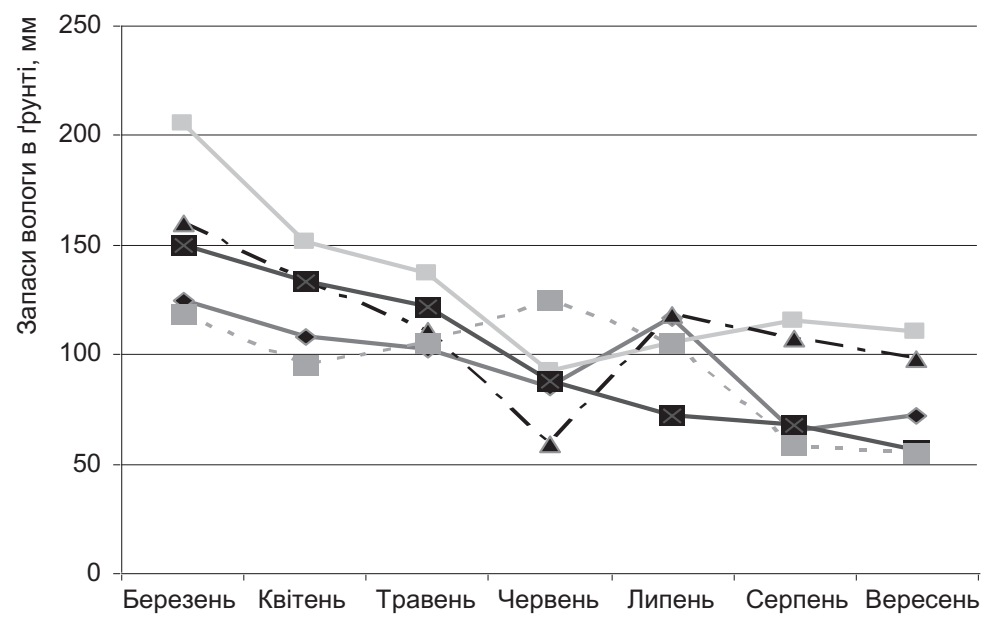

Рис. 1. Запаси вологи в дерново-підзолистому ґрунті (шар 0-100 см) упродовж вегетаційного періоду 2016-2020 рр.: —— - 2016; —- - 2017; - - - - 2018; - - - 2019; - -1 - - 2020 
АГРОЕКОЛОГІЯ, РАДІОЛОГІЯ, МЕЛІОРАЦІЯ
Максимальну реалізацію продуктивності жита озимого забезпечило поєднане застосування соломи з підвищеною в 1,5 раза нормою мінеральних добрив $\mathrm{N}_{90} \mathrm{P}_{90} \mathrm{~K}_{90}$ за роздільного (у 3 етапи) внесення азоту, за якого врожайність зерна становила 3,94 т/га (63,5\% приросту до контролю або $9,1 \%$ - до рекомендованої норми на фроні соломи).

Велике значення для товаровиробників сільськогосподарської продукції має її якість, від якої залежить закупівельна ціна і прибуток. Маса 1000 зерен свідчить про технічну цінність зерна, натура зерна має велике значення при його переробці хлібопекарськими підприємствами, а білок визначає його борошномельні та хлібопекарські властивості [10].

Виповненість зерна жита озимого в середньому за роки досліджень істотно не змінювалася від системи удобрення. Маса 1000 насінин $є$ генетично зумовленим показ- ником і тому незалежно від зовнішніх фракторів коливається в досить вузьких межах. Вона становила від 37,9 г на контролі до 40,2 г за органо-мінерального живлення, зміни у варіантах удобрення не перевищували найменшої істотної різниці (табл. 2).

Показник натури зерна жита був у межах 641-663 г/л, різниця залежно від усіх чинників впливу - неістотна.

Система удобрення сприяла підвищенню вмісту білка в зерні. Його приріст щодо контролю спостерігався при застосуванні рекомендованої норми мінеральних добрив, зокрема на фоні соломи. Найвищий уміст білка в зерні жита озимого відзначено на підвищеному фоні $\mathrm{N}_{90} \mathrm{P}_{90} \mathrm{~K}_{90}$ у поєднанні з побічною продукцією - 13,0 \%. Дослідженнями встановлено, що білковість зерна істотно залежала від погодних умов. Скажімо, у більш вологому 2018 р. вміст білка в зерні жита становив 10,4-11,7 \%, у посушливому 2019 р. - 11,7-13,2\%.

\section{1. Продуктивність жита озимого залежно від системи удобрення (2016-2020 рр.)}

\begin{tabular}{|c|c|c|c|c|c|c|c|}
\hline \multirow{2}{*}{$\begin{array}{c}\text { Ва- } \\
\text { ріант }\end{array}$} & \multirow{2}{*}{$\begin{array}{c}\text { Система } \\
\text { удобрення }\end{array}$} & \multicolumn{6}{|c|}{ Урожайність за роками, т/га } \\
\hline & & 2016 & 2017 & 2018 & 2019 & 2020 & Середнє \\
\hline 1 & Без добрив (контроль) & 2,05 & 2,77 & 2,81 & 2,25 & 2,15 & 2,41 \\
\hline 2 & Солома & 2,38 & 3,16 & 3,12 & 2,52 & 2,32 & 2,69 \\
\hline 3 & $\mathrm{~N}_{60} \mathrm{P}_{60} \mathrm{~K}_{60}{ }^{*}$ & 3,04 & 3,87 & 4,05 & 3,34 & 3,19 & 3,50 \\
\hline 4 & Солома $+\mathrm{N}_{30} \mathrm{P}_{30} \mathrm{~K}_{30}{ }^{*}$ & 2,90 & 3,54 & 3,69 & 3,20 & 2,92 & 3,25 \\
\hline 5 & Солома $+\mathrm{N}_{60} \mathrm{P}_{60} \mathrm{~K}_{60}{ }^{*}$ & 3,20 & 4,12 & 4,15 & 3,50 & 3,10 & 3,61 \\
\hline 6 & Солома $+\mathrm{N}_{90} \mathrm{P}_{90} \mathrm{~K}_{90}{ }^{* *}$ & 3,28 & 4,50 & 4,85 & 3,61 & 3,44 & 3,94 \\
\hline & $\mathrm{HIP}_{05}$ & 0,17 & 0,35 & 0,31 & 0,28 & 0,26 & 0,25 \\
\hline
\end{tabular}

2. Якісні показники зерна жита озимого залежно від системи удобрення середнє за 20162020 pp.

\begin{tabular}{|c|c|c|c|c|}
\hline \multirow{2}{*}{ Варіант } & \multirow{2}{*}{ Система удобрення } & \multicolumn{3}{|c|}{ Якісні показники зерна } \\
\hline & & вага 1000 насінин, г & натура, г/л & уміст білка, \% \\
\hline 1 & Без добрив (контроль) & 37,9 & 641 & 11,2 \\
\hline 2 & Солома & 39,4 & 650 & 11,8 \\
\hline 3 & $\mathrm{~N}_{60} \mathrm{P}_{60} \mathrm{~K}_{60}$ & 39,8 & 660 & 12,2 \\
\hline 4 & Солома $+\mathrm{N}_{30} \mathrm{P}_{30} \mathrm{~K}_{30}$ & 39,2 & 654 & 11,8 \\
\hline 5 & Солома $+\mathrm{N}_{60} \mathrm{P}_{60} \mathrm{~K}_{60}$ & 40,2 & 658 & 12,1 \\
\hline \multirow[t]{2}{*}{6} & Солома $+\mathrm{N}_{90} \mathrm{P}_{90} \mathrm{~K}_{90}$ & 40,2 & 663 & 13,0 \\
\hline & $\mathrm{HIP}_{05}$ & 3,15 & 38,5 & 1,02 \\
\hline
\end{tabular}




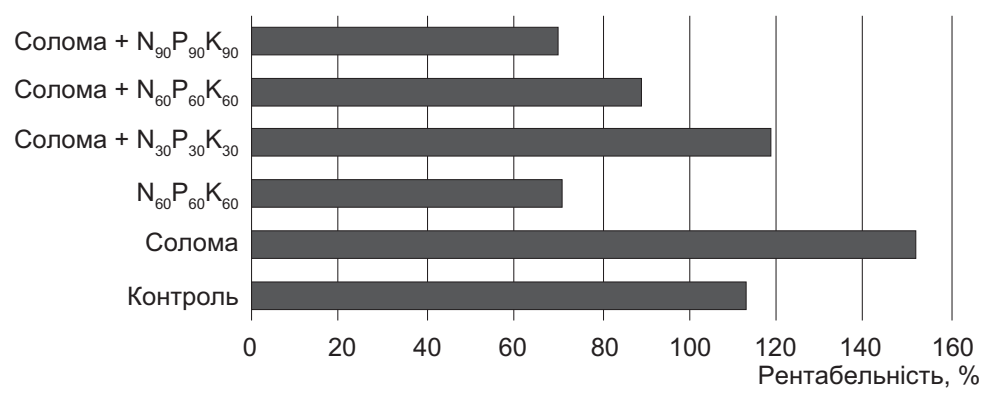

Рис. 2. Рівень рентабельності вирощування жита озимого залежно від системи удобрення

Рівень економічної діяльності вирощування культури $є$ основним критерієм результативності проведених досліджень [11]. Розрахунки економічної ефективності проводили з метою визначення найбільш оптимальної системи удобрення для жита озимого щодо якості продукції та економічної доцільності. Ці показники визначали згідно з ціновою кон'юнктурою на насіння, пальне, добриво тощо в 2020 р. Реалізаційна ціна зерна жита озимого становила 6500 грн/т.

Найвищий рівень рентабельності вирощування жита був за біологічної системи удобрення (побічна продукція ріпаку озимого) - $152 \%$, за зниженої на 50 \% норми мінеральних добрив (солома $+\mathrm{N}_{30} \mathrm{P}_{30} \mathrm{~K}_{30}$ ) 119, на контролі - $113 \%$ (рис. 2).

За використання рекомендованої $\mathrm{N}_{60} \mathrm{P}_{60} \mathrm{~K}_{60}$ та підвищеної $\mathrm{N}_{90} \mathrm{P}_{90} \mathrm{~K}_{90}$ норм, зокрема із застосуванням соломи, рентабельність знизилася до $70-89 \%$, хоча врожайність підвищилася в середньому на 33\%. Тобто затрати на застосування мінеральних добрив підвищують якість продукції і її собівартість, знижують рентабельність виробництва зерна.

\section{Висновки}

В умовах низького вологозабезпечення осушуваного дерново-підзолистого грунту в середньому за 2016-2020 рр. найвищу врожайність жита озимого отримано на рівні 3,94 m/2а за якісних показників - умісту білка в зерні - 13,0 \%, маси 1000 насінин - 40,2 2, натури зерна 663 г/л за внесення мінеральних добрив $N_{90} P_{90} K_{90}$ на фроні побічної продукції попе-

Ryzhuk S. ${ }^{1}$, Melnychuk A. ${ }^{2}$, Savchuk $0 .{ }^{3}$, Kochyk H. ${ }^{4}$, Pryimachuk T. ${ }^{5}$

Instytute of agriculture of Polissia region of NAAS, 131, Kyivske shose, Zhytomyr, 10007, Ukraine; e-mail: 2andriy_melnychuk@ukr.net, ${ }^{3-4}$ grunt17isgp@gmail.com, 5isgp.ek@gmail.com; ORCID: 20000-0002-7879-3691, ${ }^{3} 0000-0002-6702-239 X$, ${ }^{5} 0000-0002-6088-1730$

The efficiency of winter rye growing on dried soils of Polissia in conditions of climate change

Goal. To study the formation of productivity and quality of winter rye grain at different levels of organo-mineral nutrition. Methods. Field - for редника (ріпаку озимого), де азот вносили в 3 етапи за фразами розвитку рослин. За такої системи удобрення зерно відповідає III класу заідно з ДСТУ4522:2006, його рекомендується використовувати для переробки на борошно та на інші продовольчі потреби. Рівень рентабельності виробництва становив $70 \%$.

stationary experiment, laboratory - to determine the quality of soil and grain by conventional techniques, processing of experimental data by using a computer program Microsoft Office Excel. Results. Observations of 2016-2020 on the dynamics of moisture reserves in sod-podzolic drained soil showed that during the formation and filling of grain stocks of productive moisture in the layer $0-100 \mathrm{~cm}$ decreased to a critical level of $60-80 \mathrm{~mm}$. In the conditions of low soil moisture supply under the biological fertilizer system (by-products of winter rape) $2.69 \mathrm{t} /$ ha of grain were obtained $(11.6 \%$ increase to absolute control). Against the background of by-products, the application for zone rate of the 


\section{АГРОЕКОЛОГІЯ, \\ РАДІОЛОГІЯ, МЕЛІОРАЦІЯ}

Ефрективність вирощування

жита озимого на осушуваних грунтах

Полісся в умовах змін клімату

recommended mineral fertilizers $\mathrm{N}_{60} \mathrm{P}_{60} \mathrm{~K}_{60}$ grain yield increased to $3.61 \mathrm{t} / \mathrm{ha}$. The highest grain productivity was observed with the use of an increased (intensive) rate of mineral fertilizers $\mathrm{N}_{90} \mathrm{P}_{90} \mathrm{~K}_{90}$ with a separate application of nitrogen in 3 stages on the background of by-products $-3.94 \mathrm{t} / \mathrm{ha}$. The fullness of rye grain did not significantly depend on the fertilizer system. The weight of 1000 seeds was $37.9-40.2 \mathrm{~g}$, the nature of the grain was in the range of $641-663 \mathrm{~g} / \mathrm{l}$. The protein content with fertilizer application in the variants was $11.8-12.2 \%$, on an increased background - 13.0, which is $1.2 \%$ more than in the biological fertilizer system.
Conclusions. The highest level of profitability of growing winter rye was in the biological system of fertilizers using by-products of winter rape $152 \%$. Although the use of the increased $\mathrm{N}_{90} \mathrm{P}_{90} \mathrm{~K}_{90}$ fertilizer system in combination with by-products resulted in the highest grain yield and protein content, the profitability of growing winter rye decreased to $70 \%$. That is, the cost of mineral fertilizers increases the cost and reduces the profitability of grain production.

Key words: moisture supply, crop rotation, fertilizer system, productivity, quality, economic efficiency.

DOI: https://doi.org/10.31073/agrovisnyk202108-09

\section{Бібліографія}

1. Сторожук В.В. Вплив агротехнічних прийомів вирощування на врожайність жита озимого у зоні Полісся. Вісник ЖНАЕУ. 2013. № 1. C. 73-79.

2. Маслак О., Радченко М. Варто вирощувати жито. АСКОЕХРЕКТ. 2011. № 2. С. 14-17.

3. Будьонний В.Ю., Башкатова Г.М. Потенційна забур'яненість ґрунту під час вирощування жита озимого. Вісник Харківського національного аграрного університету. Серія «Рослинництво, селекція і насінництво, плодоовочівництво і зберігання». 2019. Вип. 2. С. 123-132. doi: 10.35550/ ISSN2413-7642.2019.02.13

4. Гриценко О.Ю. Урожайність сортів жита озимого за органічного виробництва в Поліссі України. Наукові горизонти. 2020. № 2 (87). C. 38-42. doi: 10.33249/2663-2144-2020-87-02$38-42$

5. Савчук O.І., Гуреля В.В., Кошицька Н.О., Іваненко Л.А. Жито озиме в сівозміні за органічного способу вирощування. Агропромислове виробництво Полісся: зб. наук. праць. Житомир, 2015. № 8. C. 24-28.

6. Урбан Э. П. Озимая рожь в Белоруси: селекция, семеноводство, технология возделывания. Минск : Беларуская наука, 2009. 269 c.

7. Melnychuk D., Khofman Dzh., Horodnii M. Yakist gruntiv ta suchasni stratehii udobrennia. Aristei. Kyiv. Ukraine. 2004. 488 p.

8. Савчук О.І., Мельничук А.О., Дребот О.В., Кудрик А.П. Вплив системи удобрення на родючість осушуваного дерново-підзолистого ґрунту в короткоротаційній сівозміні. Землеустрій, кадастр і моніторинг земель. 2020. № 1. C. 108-117. doi. 10.31548/zemleustriy2020.01.11

9. Тараріко Ю.О., Сайдак Р.В., Сорока Ю.В. Перспективи використання меліорованих земель гумідної зони України в умовах змін клімату. Вісник аграрної науки. 2016. №7. С. 55-59.

10. Лихочвор В.В., Петриченко В.Ф., Іващук П.В. Зерновиробництво. Львів: НВФ «Українські технології», 2008. 624 с.

11. Олійник О.В., Скромна О.Ю. Інтегральна оцінка ефективності управління формуванням прибутку від реалізації продукції в сільськогосподарських підприємствах. Економіка АПК: 2016. № 4. С. 75-80. 